\title{
CIÊNCIANATURA
}

\section{Linear alkanes as a tool to evaluate intraspecific differences in social wasps}

\author{
Kamylla Balbuena Michelutti ${ }^{1,2^{*}}$, Claudia Andrea Lima Cardoso ${ }^{1}$ \\ and William Fernando Antonialli-Junior ${ }^{1,2}$
}

${ }^{1}$ Centro de Estudos em Recursos Naturais, Universidade Estadual de Mato Grosso do Sul, Dourados, Brazil

${ }^{2}$ Laboratório de Ecologia Comportamental, Universidade Estadual de Mato Grosso do Sul, Dourados, Brazil

\begin{abstract}
Cuticular hydrocarbons are found in the epicuticle of insects and act during interactions between nestmates in social insects. Among the classes of these compounds, branched alkanes stand out acting as flags during intracolonial interactions, therefore, varying significantly intraspecificaly. However, there is evidence that linear alkanes can also act as signals in these interactions and therefore would also be important to assess intraspecific differences in colonies of social insects. Thus, the hypothesis of this study is that linear alkanes can be used as a tool to establish intraspecific relationships in a species of social wasp. Linear alkanes of all developmental stages were evaluated from colonies of the species Mischocyttarus consimilis Zikán (Hymenoptera, Vespidae). 21 linear alkanes were detected, with the majority ranging from $n-C_{26}$ to $n-C_{33}$. There is significant variation between the compounds of all developmental stages, both from samples of different colonies and populations. Therefore, the results validate the hypothesis that variation in composition of linear alkanes can be useful to assess intraspecific differences in social wasps.
\end{abstract}

Keywords: Developmental stages; Epicuticle; Nest material; Wasp population

\section{Resumo}

Os hidrocarbonetos cuticulares são encontrados na epicutícula dos insetos e atuam durante as interações entre companheiras de ninho em insetos sociais. Dentre as classes destes compostos, se destacam na literatura, os alcanos ramificados atuando como sinalizadores durante interações intracoloniais, assim sendo, variam intraespecificamente de forma significativa. Contudo, há evidências de que os alcanos lineares também podem atuar como sinalizadores nas interações e, portanto também seriam importantes para avaliar diferenças intraespecíficas em colônias de insetos sociais. Posto isto, a hipótese deste estudo é de que os alcanos lineares podem ser usados como ferramenta para estabelecer relações intraespecificas em uma espécie de vespa social. Foram avaliados os alcanos lineares de todos os estágios de desenvolvimento de colônias da espécie Mischocyttarus consimilis Zikán (Hymenoptera, Vespidae). Foram detectados no total 21 alcanos lineares, com os majoritários variando do $n-C_{26}$ ao $n-C_{33}$. Há uma variação significativa tanto entre os compostos de todos os estágios de desenvolvimento, de amostras de colônias diferentes, quanto de amostras de populações diferentes. Portanto, os resultados validam a hipótese de que a variação da composição de alcanos lineares podem ser úteis para avaliar diferenças intraespecificas em vespas sociais

Palavras-chave: Estágios de Desenvolvimento; Epicutícula; Material do Ninho; População de Vespas

\footnotetext{
*kamylla_michelutti@yahoo.com.br
} 


\section{Introduction}

The cuticle of insects is composed by the epicuticle, which is the outermost layer of their exoskeleton, an important structure for the success of this group (GULLAN; CRANSTON, 2007). This layer consists of a range of compounds that act on protection against desiccation and part of these compounds are the cuticular hydrocarbons (CHCs), which are composed of carbon chains, generally 20-40, especially, long chain linear alkanes, alkenes, methyl branched alkanes and polymethyl alkanes (BROWN et al., 1991; LORENZI et al., 2004; MARTIN et al., 2004, ZHU et al., 2006). Besides preventing dehydration these compounds also act as a barrier against microorganisms and play other biochemical, physiological and semiochemical functions (HOWARD; BLOMQUIST, 2005).

The CHCs function as chemical signals for intra- and interspecific communication, especially in social insects (BORGES et al., 2012). These compounds act on the receiver individual producing specific physiological or behavioral responses (GULLAN; CRANSTON, 2007). And, when involved in intraspecific communication they function as a specific type of pheromone called superficial or contact pheromones (BLOMQUIST; BAGNÉRES, 2010). Contact pheromones have long chains and are found in the epicuticle, differently from those secreted by exocrine glands present all over the body, which are light and volatile molecules (HOWARD, 1993).

These compounds act directly in the recognition between nestmates, which is fundamental to maintain cohesion in colonies of social insects, protecting them from foreign exploitation, especially by members of other colonies (DANI et al., 2004). This recognition mechanism occurs through chemical markers that in social insects function as chemical codes used to encrypt the membership of an individual in the colony (HEFETZ, 2007), giving the colony a profile, i.e. a particular "smell". In general, it is likely that these odors present in epicuticle are partly determined by genetic components (HOWARD; BLOMQUIST, 2005), and partly acquired from environmental components through interactions with other colony members and in the case of social insects, through interaction with their own nest (ESPELIE; HERMANN, 1990; COTONESCHI et al., 2007). Therefore, this process allows the wasps to acquire a chemical profile corresponding to their nest and nestmates (LORENZI et al., 2004) which may vary significantly among different populations of a specie, as already found by DAPPORTO et al. (2004a), comparing CHCs composition among three populations of Polistes dominula (Christ) (Hymenoptera, Vespidae).

These compounds are present from the egg stage, creating a chemical identity for each stage and mediating the interactions between them (ESPELIE; HERMANN, 1990; BROWN et al., 1991; PANEK; GAMBOA, 2000). The larval epicuticular substances are sufficient for recognition of larvae by adults in colonies of the wasp $P$. dominula (COTONESCHI et al., 2007). Indeed, have differences between the composition of CHCs between all stages of development of Mischocyttarus consimilis Zikán (Hymenoptera, Vespidae) (MICHELUTTI et al., 2017).

The hydrocarbons composition present in nest material also plays a central role in this recognition system (ESPELIE; HERMANN, 1990; COTONESCHI et al., 2007). In the studies developed with Polistes annularis (Linnaeus) (Hymenoptera, Vespidae) (ESPELIE; HERMANN, 1990) and with Protopolybia exigua (Saussure) (Hymenoptera, Vespidae) (SILVA et al., 2016) the authors evaluating the chemical composition of nest material and confirmed that the CHCs present in these matrices are the same found in the epicuticle of adult wasps.

Three classes of compounds present in the epicuticle of social insects are important to the assist in intraspecific communication: linear alkanes, branched alkanes and alkenes (HEFETZ, 2007). Interestingly, although several studies have stressed branched alkanes as determinants for this function (BONAVITA-COUGOURDAN et al., 1991; DANI et al., 1996; LORENZI et al., 1997; MURAKAMI et al., 2015), the behavioral and chemical studies demonstrate that this category of compounds may also be effective as signals during nest-mate interactions, suggesting that these compounds could be used as a tool to evaluate intraspecific differences between social wasps colonies (LORENZI et al., 2004; TANNURE-NASCIMENTO et al., 2007).

Therefore, since there is evidence that linear alkanes also have a significant role in mediating interactions between nestmates and that they can vary significantly among colonies, the aim of this study was to test the hypothesis that using only this category of compounds it is possible to assess intraspecific differences in social wasps, using the wasp M. consimilis as a model. 


\section{Material and methods}

Twelve colonies of the social wasp M. consimilis, all in post-emergence phase (JEANNE, 1972), were collected from June 2013 to February 2014 from two municipalities in the state of Mato Grosso do Sul, Dourados

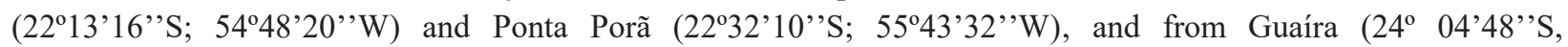
$54^{\circ} 15^{\prime} 21^{\prime \prime} \mathrm{W}$ ) in the state of Paraná, Brazil. Four colonies were collected from each of these sites for analysis of epicuticular chemical compounds of immatures, adults and nests material. All colonies were withdrawn from the nesting site at dusk involving them with a plastic container and then detaching the nest peduncle from the substrate.

All adults were killed by freezing and kept individually stored in eppendorfs at $-20^{\circ} \mathrm{C}$. Larvae were measured with the aid of a stereo microscope Leica S6D coupled to an ocular micrometer. Larval instar determination was carried out by measurement of cephalic capsule width, according to the method proposed by Dyar (PARRA; HADDAD, 1989).

\subsection{Analysis of cuticular chemical compounds}

Cuticular chemical compounds from the whole individuals of all developmental stages, from eggs to adults, were analyzed. From each nest, it was extracted a sample of $1 \mathrm{~cm}^{2}$ from the central cells.

Epicuticular and nest material compounds were extracted by immersion of each individual and nest samples in $2 \mathrm{ml}$ of hexane HPLC grade, stirring gently for $2 \mathrm{~min}$ at room temperature. Then, the samples were removed and the solvent was dried by evaporation.

Immediately before analysis, $50 \mu \mathrm{L}$ of hexane were added for solubilization of samples and standard mixture of linear hydrocarbons. The samples were analyzed using a Gas Chromatograph with Flame Ionization Detector GC-FID (Thermo Scientific - Focus GC, San Jose, CA, USA), with capillary column OV-5 (Ohio Valley Specialty Company, Marietta, OH, USA) 5\% phenyl dimethylpolysiloxane (30 m length x $0.25 \mathrm{~mm}$ internal diameter $\mathrm{x} 0.25 \mu \mathrm{m}$ film thickness). Injection of $1 \mu \mathrm{L}$ in splitless mode. Injector and detector temperature was 280 ${ }^{\circ} \mathrm{C} . \mathrm{N}_{2}(99.999 \%)$ was used as carrier gas at a flow rate of $1.0 \mathrm{~mL} \mathrm{~min}{ }^{-1}$. Heating ramp with initial temperature of $130{ }^{\circ} \mathrm{C}$, reaching $280{ }^{\circ} \mathrm{C}$ at a rate of $8{ }^{\circ} \mathrm{C} \mathrm{min}{ }^{-1}$ and remaining at $280{ }^{\circ} \mathrm{C}$ for 20 minutes. Chromatograms were recorded by Chrom Quest 5.0 program and analyzed by Workstation Chrom Data Review program.

The peak area of each compound was determined by manual integration of each total ion chromatogram (TIC). Then, all areas were transformed into relative area percent. The standard mixture of linear alkanes $\left(n-\mathrm{C}_{10}\right.$ to $n$-C 40 , Sigma Aldrich with purity $\geq 90 \%$ ) was employed for identification of epicuticular hydrocarbons from the samples by comparison of retention times. This method was described and used by FERREIRA et al. (2012) and FERREIRA et al. (2017).

\subsection{Statistical analysis}

Four different analyses were performed using SYSTAT 12 software (San Jose, CA, USA) to determine the importance of linear alkanes to assess differences between the samples. For the first analysis, it was used the relative areas of all peaks detected, i.e. all compounds present in samples of all populations. For the second analysis, it was used only the relative areas of linear alkanes in order to evaluate the role of these compounds to assess the variation between samples from different populations. In the third, it was evaluated the variation of these compounds between different developmental stages and nest material, for each population separately. For this analysis, only last-instar larvae were used due to the relatively large number of samples. Finally, to assess more carefully the linear alkanes variation between the different developmental stages and nest material, it was used the relative areas of these compounds, only from the population of Dourados, MS, in order to minimize the effect of the variations generated by different types of nesting environments (BROWN et al., 1991; LORENZI et al., 1997).

Knowing that the levels of CHCs recovered vary according to the material examined and that studies demonstrate that, especially for larvae, these contents are relatively low (ESPELIE; HERMANN, 1990), only the compounds with relative area percent above $1 \%$ were considered significant. 


\section{Results and discussion}

Discriminant analysis with all detected peaks showed that there are no significant differences between cuticular compounds of all stages and nest material among all populations, with Wilks's Lambda $=0.001 ; \mathrm{F}=1.032$ and $\mathrm{p}=0.399$.

Twenty one linear alkanes were identified with carbonic chain varying in content and number of compounds from $n-\mathrm{C}_{14}$ to $n$ - $\mathrm{C}_{35}$, present in the different developmental stages and also in the nest material (Table 1 and Figure 1). Indeed, several compounds of this class were detected in other studies, which identified $n$-alkanes ranging from $n-\mathrm{C}_{23}$ to $n-\mathrm{C}_{29}$ in nest material and cuticle of workers, males, larvae and eggs of the social wasp $P$. annularis (ESPELIE; HERMANN, 1990) and compounds ranging from $n-\mathrm{C}_{22}$ to $n$ - $\mathrm{C}_{36}$ in larvae and adults of $P$. dominula (COTONESCHI et al., 2007).

Table 1 - Linear alkanes content assessed by GC-FID of samples from different developmental stages and nest material of Mischocyttarus consimilis from different populations

\begin{tabular}{|c|c|c|c|c|c|c|c|c|c|}
\hline \multirow[b]{2}{*}{ LA } & \multicolumn{9}{|c|}{ Stage of development (Average \pm SD (\%)) } \\
\hline & Egg & $1^{\text {st }}$ instar & $2^{\text {nd }}$ instar & $3^{\text {rd }}$ instar & $4^{\text {th }}$ instar & $5^{\text {th }}$ instar & Pupae & Adult & Nest \\
\hline $\mathrm{C}_{14}$ & $1.01 \pm 5.47$ & - & $0.19 \pm 0.83$ & - & - & - & - & $0.12 \pm 0.64$ & - \\
\hline $\mathrm{C}_{15}$ & $1.07 \pm 5.77$ & - & - & - & - & - & - & - & - \\
\hline $\mathrm{C}_{16}$ & $0.02 \pm 0.08$ & $0.05 \pm 0.21$ & - & - & - & $0.02 \pm 0.10$ & - & - & $0.03 \pm 0.05$ \\
\hline $\mathrm{C}_{17}$ & $1.12 \pm 1.57$ & $0.46 \pm 0.76$ & $0.34 \pm 0.69$ & - & $0.3 \pm 0.52$ & $0.33 \pm 0.56$ & $0.01 \pm 0.04$ & - & $0.04 \pm 0.06$ \\
\hline $\mathrm{C}_{18}$ & $0.18 \pm 0.31$ & $0.61 \pm 1.95$ & $0.52 \pm 1.07$ & $0.12 \pm 0.53$ & $0.35 \pm 0.69$ & $0.16 \pm 0.36$ & $0.10 \pm 0.22$ & $0.51 \pm 0.68$ & $0.07 \pm 0.07$ \\
\hline $\mathrm{C}_{19}$ & $0.27 \pm 1.02$ & $0.04 \pm 0.18$ & $0.29 \pm 0.49$ & - & $0.19 \pm 0.56$ & $0.23 \pm 0.40$ & $0.14 \pm 0.28$ & $0.01 \pm 0.04$ & $0.08 \pm 0.10$ \\
\hline $\mathrm{C}_{20}$ & $1.23 \pm 3.14$ & $0.53 \pm 1.55$ & $1.15 \pm 1.55$ & $0.53 \pm 1.65$ & $0.55 \pm 1.10$ & $0.43 \pm 1.30$ & $0.44 \pm 1.11$ & $0.52 \pm 0.63$ & $0.09 \pm 0.10$ \\
\hline $\mathrm{C}_{21}$ & $1.45 \pm 4.26$ & $0.58 \pm 1.70$ & $1.48 \pm 2.85$ & $0.69 \pm 2.29$ & $0.78 \pm 1.76$ & $0.35 \pm 0.77$ & $1.71 \pm 5.96$ & $0.47 \pm 0.55$ & $0.12 \pm 0.12$ \\
\hline $\mathrm{C}_{22}$ & $3.26 \pm 7.76$ & $2.53 \pm 5.00$ & $2.14 \pm 2.44$ & $1.01 \pm 2.29$ & $0.92 \pm 1.49$ & $0.92 \pm 1.99$ & $1.20 \pm 2.92$ & $0.91 \pm 0.89$ & $0.34 \pm 0.43$ \\
\hline $\mathrm{C}_{23}$ & $1.71 \pm 2.99$ & $1.54 \pm 5.59$ & $1.46 \pm 2.43$ & $0.09 \pm 0.28$ & $0.59 \pm 0.65$ & $0.74 \pm 1.94$ & $1.01 \pm 1.48$ & $0.51 \pm 0.54$ & $0.20 \pm 0.24$ \\
\hline $\mathrm{C}_{24}$ & $1.41 \pm 2.34$ & $1.63 \pm 4.40$ & $1.15 \pm 1.59$ & $0.44 \pm 1.01$ & $1.75 \pm 5.36$ & $1.10 \pm 1.62$ & $1.21 \pm 2.12$ & $1.53 \pm 2.29$ & $0.59 \pm 0.70$ \\
\hline $\mathrm{C}_{25}$ & $1.91 \pm 2.77$ & $2.34 \pm 3.41$ & $2.67 \pm 3.07$ & $1.82 \pm 2.81$ & $2.06 \pm 2.33$ & $2.86 \pm 3.28$ & $3.13 \pm 10.32$ & $0.75 \pm 0.66$ & $0.29 \pm 0.35$ \\
\hline $\mathrm{C}_{26}$ & $1.67 \pm 3.15$ & $1.43 \pm 1.42$ & $2.66 \pm 2.95$ & $2.32 \pm 3.14$ & $2.49 \pm 3.48$ & $3.94 \pm 4.75$ & $2.25 \pm 4.82$ & $2.16 \pm 2.54$ & $0.95 \pm 0.85$ \\
\hline $\mathrm{C}_{27}$ & $3.99 \pm 4.55$ & $3.6 \pm 4.09$ & $3.77 \pm 2.81$ & $3.60 \pm 4.65$ & $8.09 \pm 15.85$ & $2.92 \pm 2.85$ & $5.39 \pm 8.37$ & $1.13 \pm 0.96$ & $1.52 \pm 3.62$ \\
\hline $\mathrm{C}_{28}$ & $4.37 \pm 4.08$ & $6.33 \pm 6.52$ & $4.88 \pm 5.42$ & $5.50 \pm 5.56$ & $4.69 \pm 7.60$ & $6.31 \pm 5.56$ & $3.39 \pm 8.22$ & $6.72 \pm 7.19$ & $4.83 \pm 3.51$ \\
\hline $\mathrm{C}_{29}$ & $7.53 \pm 6.87$ & $8.10 \pm 6.39$ & $5.75 \pm 5.42$ & $6.50 \pm 6.03$ & $5.22 \pm 5.92$ & $6.13 \pm 6.83$ & $9.48 \pm 11.72$ & $4.16 \pm 4.60$ & $2.05 \pm 2.95$ \\
\hline $\mathrm{C}_{30}$ & $8.64 \pm 9.25$ & $10.26 \pm 11.34$ & $14.64 \pm 17.80$ & $13.94 \pm 15.3$ & $7.63 \pm 8.74$ & $11.62 \pm 9.16$ & $6.59 \pm 7.55$ & $13.00 \pm 14.15$ & $10.35 \pm 8.78$ \\
\hline $\mathrm{C}_{31}$ & $3.45 \pm 2.91$ & $11.13 \pm 16.13$ & $4.10 \pm 3.97$ & $4.24 \pm 2.91$ & $3.59 \pm 3.44$ & $5.70 \pm 5.23$ & $9.41 \pm 9.15$ & $7.57 \pm 8.48$ & $17.81 \pm 16.60$ \\
\hline $\mathrm{C}_{32}$ & $3.72 \pm 6.25$ & $4.69 \pm 5.30$ & $3.47 \pm 3.86$ & $4.98 \pm 4.87$ & $5.96 \pm 8.99$ & $5.32 \pm 8.37$ & $2.95 \pm 4.61$ & $2.02 \pm 1.69$ & $3.60 \pm 2.09$ \\
\hline $\mathrm{C}_{33}$ & $1.76 \pm 2.64$ & $1.72 \pm 2.15$ & $1.37 \pm 2.03$ & $1.39 \pm 2.46$ & $2.10 \pm 4.11$ & $1.93 \pm 3.32$ & $4.71 \pm 8.24$ & $5.66 \pm 7.73$ & $2.58 \pm 3.35$ \\
\hline $\mathrm{C}_{34}$ & $0.29 \pm 1.11$ & $2.91 \pm 8.04$ & $1.19 \pm 2.75$ & $4.97 \pm 11.65$ & $4.28 \pm 10.30$ & $3.56 \pm 14.85$ & $0.73 \pm 0.86$ & $0.39 \pm 0.60$ & $0.64 \pm 1.20$ \\
\hline $\mathbf{C}_{35}$ & $0.05 \pm 0.19$ & $0.30 \pm 0.75$ & $6.36 \pm 19.08$ & $0.95 \pm 3.01$ & $0.93 \pm 2.80$ & $0.34 \pm 1.16$ & $3.1 \pm 8.54$ & $0.2 \pm 0.96$ & $0.59 \pm 0.53$ \\
\hline
\end{tabular}

$\mathrm{SD}=$ Standard deviation; $\mathrm{LA}=$ Linear alkanes

All 21 linear alkanes were found in samples of eggs and nest material. The compounds from $n-\mathrm{C}_{15}$ to $n-\mathrm{C}_{17}$ were detected only in in all immatures and nest material, and the compounds from $n$ - $\mathrm{C}_{18}$ to $n$ - $\mathrm{C}_{35}$ occurred in all developmental stages, from egg to adult (Figure 1). Therefore, there is significant qualitative and quantitative variation between the composition of linear alkanes in all samples. In Polistes versicolor (Olivier) (Hymenoptera: Vespidae) also have significant variation between levels of linear alkanes in the developmental stages (BRITO et al., 2015). The Table 1 presents, in many cases, high deviation in averages of linear alkanes present in the 
developmental stages and nest material, which is a recurring variation of samples from different colonies and populations.

Figure 1 - Percentage and number of linear alkanes in samples of different developmental stages and nest material of Mischocyttarus consimilis from different populations

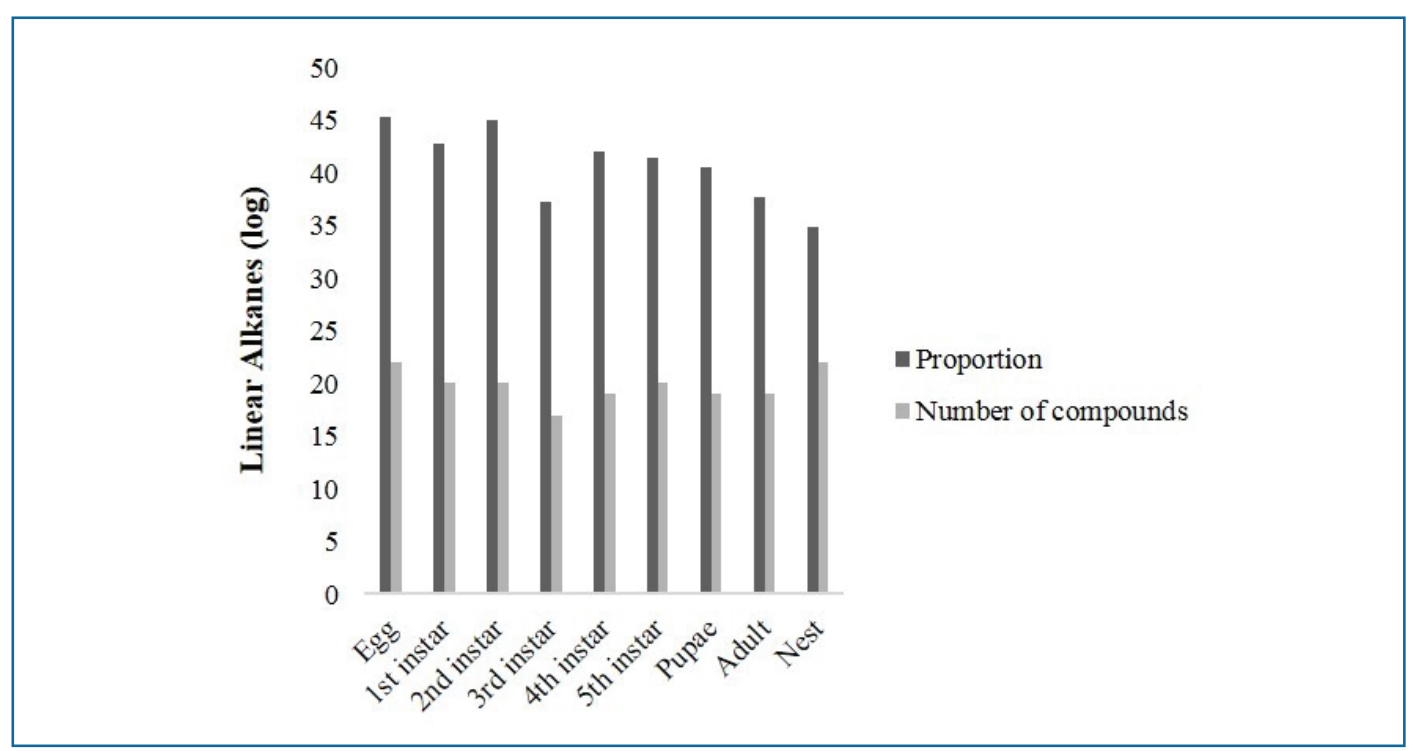

The alkanes from $n-\mathrm{C}_{26}$ to $n$ - $\mathrm{C}_{33}$ were considered major compounds because they presented content above $1 \%$ in all samples. The alkanes $n$ - $\mathrm{C}_{29}(7.5 \%)$ and $n$ - $\mathrm{C}_{30}(8.6 \%)$ were the major compounds for eggs, $n$ - $\mathrm{C}_{30}(10.3 \%)$ and $n-\mathrm{C}_{31}(11.1 \%)$ for first instar larvae, $n-\mathrm{C}_{29}(5.7 \%)$ and $n-\mathrm{C}_{30}(14.6 \%)$ for second instar larvae, $n-\mathrm{C}_{29}(6.5 \%)$ and $n$ $\mathrm{C}_{30}(13.9 \%)$ for third instar larvae, $n-\mathrm{C}_{27}(8.1 \%)$ and $n-\mathrm{C}_{30}(7.6 \%)$ for fourth instar larvae, $n-\mathrm{C}_{28}(6.3 \%)$ and $n-\mathrm{C}_{30}$ (11.6\%) for fifth instar larvae, $n-\mathrm{C}_{29}(9.5 \%)$ and $n-\mathrm{C}_{31}(9.4 \%)$ for pupae, $n-\mathrm{C}_{30}(13.0 \%)$ and $n-\mathrm{C}_{31}(7.6 \%)$ for adults and, finally, $n-\mathrm{C}_{30}(10.3 \%)$ and $n-\mathrm{C}_{31}(17.8 \%)$ were the major compounds for nest material (Table 1).

The analysis with only the relative areas of linear alkanes showed significant differences between the chemical composition of samples from different populations, with Wilks's Lambda $=0.146 ; \mathrm{F}=2.897 ; \mathrm{p}<0.001$ (Figure 2). Our results show that linear alkanes are indeed important to assess differences in composition of the samples. The most significant compounds to distinguish the groups were $n-\mathrm{C}_{14}$ and from $n-\mathrm{C}_{16}$ to $n-\mathrm{C}_{34}$. Although the analysis showed that there are significant differences between cuticular chemical composition, it is possible to observe an overlap of groups in Figure 2, probably due to genetic similarities and environmental conditions to which the colonies were exposed. For example, in Polistes fuscatus (Fabricius) (Hymenoptera: Vespidae) females are more tolerant towards immatures from colonies nested closer to their own colony than those nested further, suggesting that the similarity of cuticular compounds of immatures is directly proportional to the distance between colonies (KLAHN; GAMBOA, 1983). In fact, exist greater similarity in cuticular chemical compounds between colonies from two neighboring populations than from a third population nested more distantly in $P$. dominula (DAPPORTO et al., 2004a).

Indeed, using only the relative areas of linear alkanes identified in the same samples, there were significant differences both when evaluating samples of all developmental stages and nests together (Figure 2) and when assessing each type of sample separately (Figure 3). The separate analysis comparing developmental stages and nest material from different populations showed that there are significant differences between compounds of eggs (Wilks' Lambda $=0.000 ; \mathrm{F}=74.671 ; \mathrm{p}<0.001 ;$ Figure 3a); larvae (Wilks' Lambda $=0.001 ; \mathrm{F}=391.695 ; \mathrm{p}<0.001$; Figure 3b); pupae (Wilks' Lambda $=0.001 ; \mathrm{F}=35.475 ; \mathrm{p}<0.001$; Figure 3c); adults (Wilks's Lambda $=0.001 ; \mathrm{F}=20.363$; $\mathrm{p}<0.001$; Figure 3d) and nest material (Wilks' Lambda $=0.001 ; \mathrm{F}=31.359 ; \mathrm{p}=0.031$; Figure 3e). The most significant peaks for separation of the groups were $n-\mathrm{C}_{14}$, from $n$ - $\mathrm{C}_{16}$ to $n-\mathrm{C}_{24}$ and from $n-\mathrm{C}_{27}$ to $n-\mathrm{C}_{35}$ for eggs; from 
$n-\mathrm{C}_{16}$ to $n-\mathrm{C}_{35}$ for fifth instar larvae; from $n-\mathrm{C}_{17}$ to $n-\mathrm{C}_{26}$ and from $n-\mathrm{C}_{28}$ to $n-\mathrm{C}_{35}$ for pupae; $n-\mathrm{C}_{14}$ and from $n-\mathrm{C}_{19}$ to $n-\mathrm{C}_{35}$ for adults; and from $n-\mathrm{C}_{14}$ to $n-\mathrm{C}_{31}$ and $n-\mathrm{C}_{35}$ for nest material.

Figure 2 - Dispersion diagram showing the differentiation in composition of linear alkanes of different developmental stages and nest material of Mischocyttarus consimilis from different populations

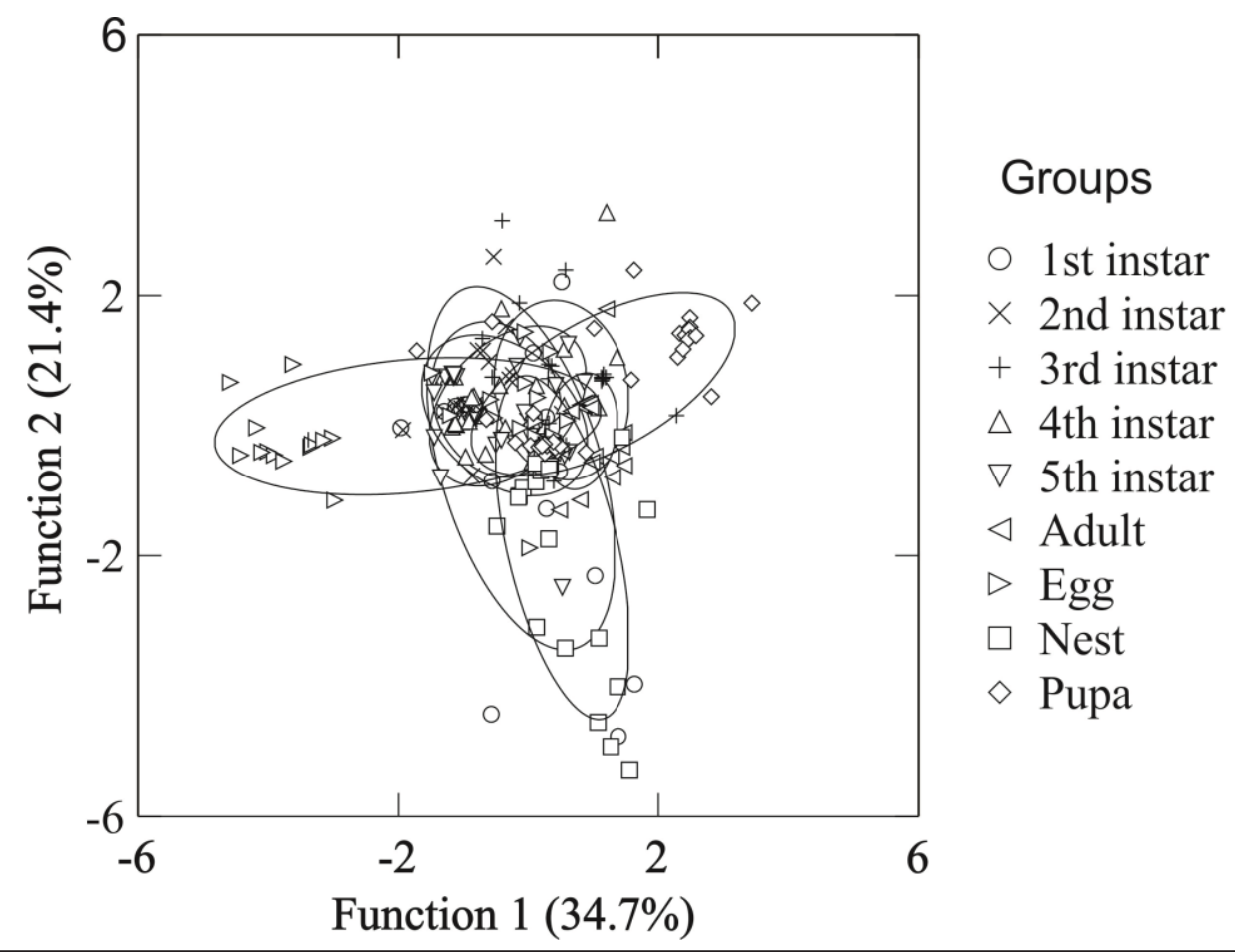

Figure 3 - Dispersion diagram showing the differentiation in composition of linear alkanes of: (a) Egg; (b) Fifth instar larvae; (c) Pupae; (d) Adults and (e) Nest material of three different populations of Mischocyttarus consimilis
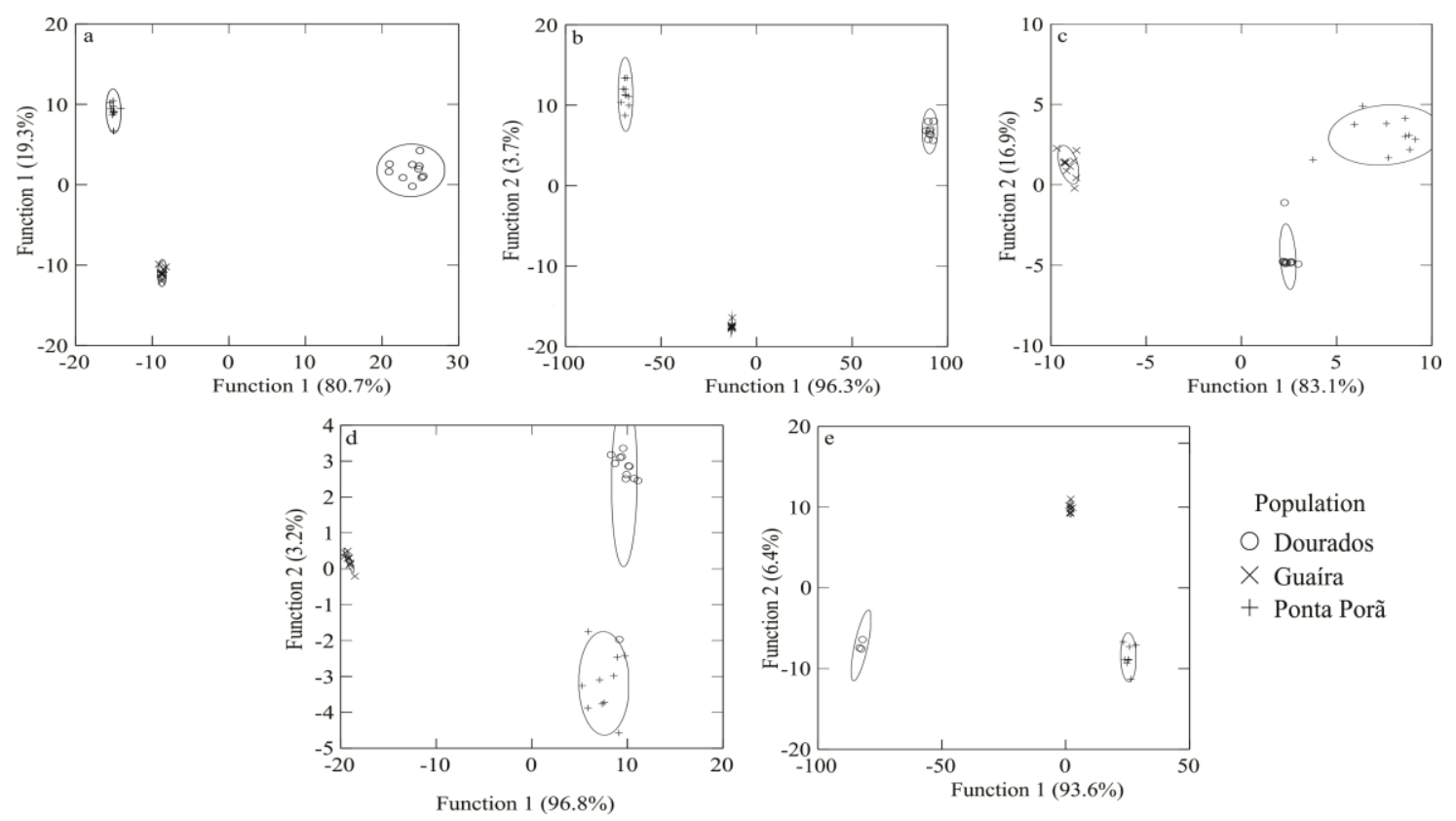

Population

Dourados

$\times$ Guaíra

+ Ponta Porã 
Finally, the analysis with only one population showed that there are significant differences between the cuticular composition of linear alkanes of the different developmental sta.ges and nest material from different colonies (Wilks's Lambda $=0.001 ; \mathrm{F}=149.941 ; \mathrm{p}<0.001$ ) (Figure 4) and the most significant compounds for separation of the groups were from $\mathrm{C}_{17}$ to $\mathrm{C}_{35}$. Figure 4 shows that linear alkane composition vary significantly among different developmental stages of different colonies from the same population, which proves that, indeed, each colony has its own chemical signature (DAPPORTO et al., 2004a, 2004b; COTONESCHI et al., 2007). Thus, although we did not perform any behavioral tests, our results suggest these compounds can be used to signal each stage during interactions in the colonies, both between adults and immatures and among adults.

\section{Figure 4 - Dispersion diagram showing the differentiation in composition of linear alkanes of different developmental} stages and nest material of Mischocyttarus consimilis from a single population

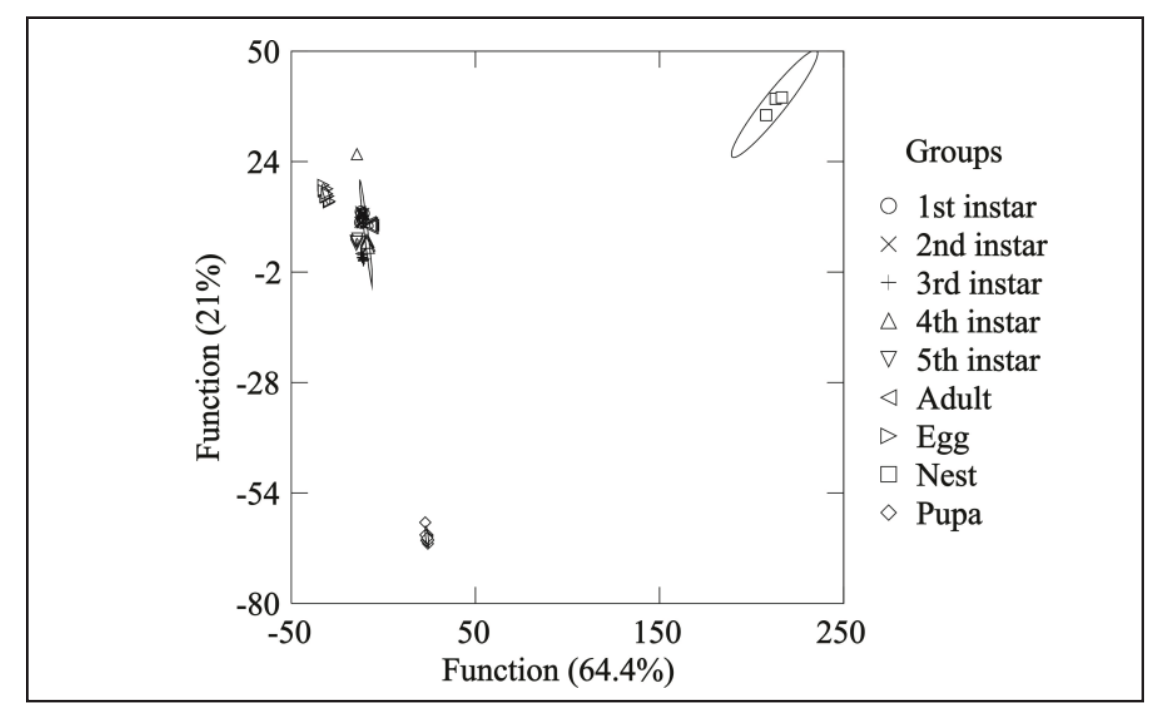

In colonies of Polistes satan Bequaert (Hymenoptera, Vespidae) that there is significant variation of linear alkanes between females of different hierarchical ranks, which suggests that they can be used to mediate interactions in colonies of this species (TANNURE-NASCIMENTO et al., 2007, 2008). Indeed, linear alkanes have also been considered key compounds for discrimination of adults younger than $24 \mathrm{~h}$ in P. dominula (LORENZI et al., 2004).

Although these results demonstrate that linear alkanes vary significantly among samples, it is not possible to infer that they are the most decisive to mediate interactions between nestmates. On the contrary, CHCs of Polistes biglumis bimaculatus (Linnaeus) (Hymenoptera, Vespidae) (LORENZI et al., 1997) and of Mischocyttarus cassununga Von Ihering (Hymenoptera, Vespidae) (MURAKAMI et al., 2015) concluded that branched alkanes are the most important compounds for chemical discrimination between nestmates in these species. What probably happens is that the different classes of compounds can vary and provide the necessary information to mediate interactions in colonies.

Through behavioral tests, have also confirmed the ability of adults to recognize larvae of their own colonies from those of other colonies in P. fuscatus (KLAHN; GAMBOA, 1983; PANEK; GAMBOA, 2000). In addition P. fuscatus uses chemical signals to discriminate their nests, offspring and even sister colonies (KLAHN; GAMBOA, 1983). Factors such as age and larval diet could also contribute to the differences and similarities in cuticular chemical composition between colonies nested in different environments (DANI et al., 2004). In this sense, the cuticular chemical composition of $P$. dominula, reflects the similarities of the habitat in which colonies are nested (DAPPORTO et al., 2004b).

As happens with the members of the colonies, chemical composition of nests also varies significantly according to population and, therefore, according to genetic factors and type of environment in which colonies are nested (Figure 3), because part of the compounds present on the surface of the epicuticle of the different developmental stages are acquired from nest material (SINGER; ESPELIE, 1992) and mainly, because when 
constructing the nest part of the compounds that are used by the wasps come from sources used as raw material, usually plant material (WENZEL, 1998). Once the results have shown that chemical profiles vary significantly according to the origin of the colonies (Figure 3), i.e. nesting sites, an analysis using samples from a single population would show more clearly the differences between cuticular chemical composition of different developmental stages (Figure 4).

The variation in chemical composition between different larval instars of $P$. dominula was evaluate from a single population in order to avoid potential biases related to environmental differences between the nesting habitats of the colonies (COTONESCHI et al., 2009). Also in order to avoid the variations inherent in environment, used only one colony to evaluate variations in chemical composition throughout the development stages of the wasp Vespula germanica (Fabricius) (Hymenoptera, Vespidae) (BROWN et al., 1991). Furthermore, the results shown in Figure 4 corroborate those for $P$. dominula which also have a chemical signature characteristic for each of the different developmental stages (COTONESCHI et al., 2007).

Distinguishing CHCs composition between larvae of different stages is important for workers, in this sence, it is possible is that these cues can signal how workers must feed the larvae (COTONESCHI et al., 2009). Knowing which larva and when to feed it differently can produce adults with different characteristics (ROSSI; HUNT, 1988), for example, to produce adult females with higher or lower reproductive potential, since there is evidence that caste determination occurs at least partly pre-imaginally in independent-founding wasps (O'DONNELL, 1998).

\section{Conclusions}

Our results show that using all classes of compounds it was not possible to detect significant differences between the different samples of this species. However, using only the linear alkanes it was possible to distinguish them significantly. Furthermore, to assess differences between the different stages of development it is better to diminish the effects of other factors, such as genetic and environmental and consider the samples of a single population.

Therefore, according to our results, it is possible to validate the hypothesis that variation in composition of linear alkanes can be useful as a complementary tool to assess intraspecific differences in social wasps and provides evidence that this class of compounds can also be important for mediating interactions in their colonies.

\section{Acknowledgment}

The authors thank Fundação de Apoio ao Desenvolvimento do Ensino, Ciência e Tecnologia do Estado de Mato Grosso do Sul (FUNDECT); SISBIO for authorization of the colletion and of the transport of the specimens (SISBIO license No.1748-1), Coordenação Aperfeiçoamento de Pessoal de Nível Superior (CAPES) provided a Masters fellowship to the fisrt author; authors WFAJ (grant number 307998/2014-2) and CALC (grant number 310801/2015-0) acknowledge research grants from the Conselho Nacional de Desenvolvimento Científico e Tecnológico (CNPq).

\section{References}

BLOMQUIST GJ, BAGNÉRES AG. Insect hydrocarbons biology, biochemistry, and chemical ecology. Published in the United States of America by Cambridge University Press, New York, 2010; p 492.

BONAVITA-COUGOURDAN A, THERAULAZ G, BAGNÉRES AG, ROUX M, PRATTE M, PROVOST E, CLÉMENT JL. Cuticular hydrocarbons, social organization and ovarian development in a polistine wasp: Polistes dominulus christ. Comp. Biochem. Physiol. 1991; 100B (4): 667-680.

BORGES AA, FERREIRA-CALIMAN MJ, NASCIMENTO FS, CAMPOS LAO, TAVARES MG. Characterization of cuticular hydrocarbons of diploid and haploid males, workers and queens of the stingless bee Melipona quadrifasciata. Insect. Soc. 2012. 
BRITO JH dos S, MONTAGNA TS, MAIA FS, ANTONIALLI-JUNIOR WF, CARDOSO CAL. Cuticular signature in the development of Polistes versicolor. Genet. Mol. Res. 2015; 14 (4): 12520-12528.

BROWN WV, SPRADBERY JP, LACEY MJ. Changes in the cuticular hydrocarbon composition during development of the social wasp, Vespula germanica (f.) (Hymenoptera: Vespidae). Comp. Biochem. Physiol. 1991; 99(3): 553-562.

COTONESCHI C, DANI FR, CERVO R, SLEDGE MF, TURILlAZZI S. Polistes dominulus (Hymenoptera: Vespidae) larvae possess their own chemical signatures. J. Insect Physiol. 2007; 53: 954-963.

COTONESCHI C, DANI FR, CERVO R, SCALA C, STRASSMANN JE, QUELLER DC, TURILLAZZI S. Polistes dominulus (Hymenoptera, Vespidae) larvae show different cuticular patterns according to their sex: workers seem not use this chemical information. Chem. Senses. 2009; 53: 195-202.

DANI FR, MORGAN ED, TURILlAZZI S. Dufour gland secretion of Polistes wasp: chemical composition and possible involvement in nestmate recognition (Hymenoptera: Vespidae). J. Insect Physiol. 1996; 42(6): 541-548.

DANI FR, FOSTER KR, ZACCHI F, SEPPA P, MASSOLO A, CARELLI A, ARÉVALO E, QUELLER DC, STRASSMAN JE, TURILLAZZI S. Can epicuticular lipids provide sufficient information for within-colony nepotism in wasps? The Royal Society. Proc. R. Soc. Lond. B. 2004; 271: 745-753.

DAPPORTO L, THEODORA P, SPACCHINI C, PIERACCINI G, TURILLAZZI S. Rank and epicuticular hydrocarbons in different populations of the paper wasp Polistes dominulus (Christ) (Hymenoptera,Vespidae). Insect. Soc. 2004a; 51: 279-286.

DAPPORTO L, PALAGI E, TURILLAZZI S. Cuticular hydrocarbons of Polistes dominulus as a biogeographic tool: a study of populations from the tuscan archipelago and surrounding areas. J. Chem. Ecol. 2004b; 30(11): 21392151.

ESPELIE KE, HERMANN HR. Surface lipids of the social wasp Polistes annularis (L.) and its nest and nest pedicel. J. Chem. Ecol. 1990; 16(6): 1841-1852.

FERREIRA AC, CARDOSO CAL, NEVES EF, SÚAREZ YR, ANTONIALLI-JUNIOR WF. Distinct linear hydrocarbon profiles and chemical strategy of facultative parasitism among Mischocyttarus wasps. Genetics and Molecular Research. 2012; 11(4): 4351-435.

FERREIRA AC, NEVES EF, MONTAGNA TS, MENDONÇA A, CARDOSO CAL., ANTONIALLI-JUNIOR WF. Intraspecific Variation of the Composition of Linear Alkanes in Social Wasp Mischocyttarus consimilis. 2017; Sociobiology. 64(4): 466-476.

GULLAN PJ, CRANSTON OS. Os Insetos: Um resumo de entomologia. $3^{\text {a }}$ ed. Roca, São Paulo. 2007; p 440.

HEFETZ A. The evolution of hydrocarbon pheromone parsimony in ants (Hymenoptera: Formicidae) - interplay of colony odor uniformity and odor idiosyncrasy. A review. Myrmecological News. 2007; 10: 59-68.

HOWARD RW. Cuticular hydrocarbon and chemical communication. In: (Stanley-Samuelson DW, Nelson DR eds.) Insect lipids: chemistry, biochemistry and biology. University of Nebraska Press, Lincoln. 1993; pp 179-226.

HOWARD RW, BLOMQUIST GJ. Ecological, behavioral, and biochemical aspects of insect hydrocarbons. Annu. Rev. Entomol. 2005; 50: 371-393.

JEANNE, RL. Social biology of the neotropical wasp Mischocyttarus drewseni. Bulletin of the Museum of Comparative Zoology. 1972; 144: 63-150.

KLAHN JE, GAMBOA GJ. Social Wasps: Discrimination between kin and nonkin brood. Science. 1983; 221: 482484. 
LORENZI MC, BAGNÈRES AG, CLÉMENT JL, TURILLAZZI S. Polistes biglumis bimaculatus epicuticular hydrocarbons and nestmate recognition (Hymenoptera, Vespidae). Insectes Soc. 1997; 44: 123-138.

LORENZI MC, SLEDGE MF, LAIOLO P, STURLINI E, TURILLAZZI S. Cuticular hydrocarbon dynamics in young adult Polistes dominulus (Hymenoptera: Vespidae) and the role of linear hydrocarbons in nestmate recognition systems. J. Insect Physiol. 2004; 50: 935-941.

MARTIN SJ, JONES GR, CHÂLINE N, RATNIEKS FLW. Role of hydrocarbons in egg recognition in the honeybee. Physiol. Entomol. 2004; 29: 395-399.

MICHELUTTI KB, CARDOSO CAL, ANTONIALLI-JUNIOR WF. Evaluation of chemical signatures in the developmental stages of Mischocyttarus consimilis Zikán (Hymenoptera, Vespidae) employing gas chromatography coupled to mass spectrometry. Rev. Virtual Quim. 2017; 9(2): 535-547.

MURAKAMI ASN, NUNES TM, DESUÓ IC, SHIMA SN, MATEUS S. The cuticular hydrocarbons profiles in the colonial recognition of the Neotropical eusocial wasp, Mischocyttarus cassununga (Hymenoptera: Vespidae). Sociobiology. 2015; 62(1): 109-115.

O’DONNELL S. Reproductive caste determination in eusocial wasps (Hymenoptera: Vespidae). Annu. Rev. Entomol.1998; 43: 323-346.

PANEK LM, GAMBOA GJ. Queens of the paper wasp Polistes fuscatus (Hymenoptera: Vespidae) discriminate among larvae on the basis of relatedness. Ethology. 2000; 106: 159-170.

PARRA JRP, HADDAD ML. Determinação do número de instares de insetos. Piracicaba: FEALQ. 1989; p 49.

ROSSI AM, HUNT JH. Honey supplementation and its developmental consequences: evidence for food limitation in a paper wasp, Polistes metricus. Ecol. Entomol. 1988; 13: 437-442.

SILVA ERS, MICHELUTTI KB, ANTONIALLI-JUNIOR WF, BATISTOTE M, CARDOSO CAL. Chemical signatures in the developmental stages of Protopolybia exigua. Genet. Mol. Res. 2016; 15(1):1-12.

SINGER TL, ESPELIE KE. Social wasps use nest paper hydrocarbons for nestmate recognition. Anim. Behav. 1992; 44: 63-68.

TANNURE-NASCIMENTO IC, NASCIMENTO FS, TURATTI IC, LOPES NP, TRIGO JR, ZUCCHI R. Colony membership is reflected by variations in cuticular hydrocarbon profile in a Neotropical paper wasp, Polistes satan (Hymenoptera, Vespidae). Genet. Mol. Res. 2007; 6 (2): 390-396.

TANNURE-NASCIMENTO IC, NASCIMENTO FS, ZUCCHI R. The look of royalty: visual and odour signals of reproductive status in a paper wasp. Proc. R. Soc. B. 2008; 275: 2555-2561.

WENZEL JW. A generic key to the nests of hornets, yellowjackets, and paper wasps worldwide (Vespidae: Vespinae, Polistinae). Am. Mus. Novit. 1998; 3224: 1-39.

ZHU GH, YE GY, HU C, XU XH, LI K. Development changes of cuticular hydrocarbons in Chrysomya rufifacies larvae: potential for determining larval age. Med. Vet. Entomol. 2006; 2: 438-444. 